DOI $10.14746 /$ ssp.2014.4.9

Magdalena MUSIAŁ-KARG, Elżbieta LESIEWICZ

Uniwersytet im. Adama Mickiewicza w Poznaniu

\title{
Od transfromacji do integracji: wybrane uwagi nt. ,bezpośredniej” partycypacji obywateli w procesie podejmowania decyzji politycznych po 1989 r. na przykładzie państw Grupy Wyszehradzkiej
}

Doziom partycypacji obywatelskiej, a także różne formy partycypacji, są ważnymi elementami dyskusji na temat kondycji współczesnej demokracji. W wielu krajach europejskich coraz częściej mówi się o kryzysie demokracji, o deficycie demokratycznym, usiłując znaleźć antidotum na małe zaangażowanie obywateli zarówno w głosowaniach powszechnych, jak i w działalności różnego rodzaju organizacji obywatelskich. Taki stan rzeczy zaobserwować można szczególnie w tzw. młodych demokracjach, do których zalicza się państwa Grupy Wyszehradzkiej - Polskę, Węgry, Czechy i Słowację - gdzie obywatele nie uczestniczą masowo w wyborach powszechnych, a poziom zaangażowania w działalność w organizacjach pozarządowych i poziom rozwoju społeczeństwa obywatelskiego oceniane są raczej jako marginalne.

Możliwość uczestnictwa w szeroko pojmowanym życiu politycznym, konstytucyjnie gwarantowany i zinstytucjonalizowany wpływ obywateli na działania organów władzy państwowej jest jedną z fundamentalnych zasad demokracji (Szczegóła, 2013, s. 18). Udział obywateli w przestrzeni publicznej przejawia się zaś w ich autentycznym udziale w sprawowaniu władzy i różnorodnych formach jej kontroli (np. wybieranie kandydatów do władz przedstawicielskich, uczestnictwo w partiach politycznych, zaangażowanie w organizacjach obywatelskich itp.). Taka aktywność polityczna obywateli jest wynikiem ich wiedzy o instytucjach i mechanizmach sprawowania władzy, świadomości swojego miejsca w społeczeństwie, poczucia więzi społecznych oraz obiektywnej oceny szeroko rozumianej bieżącej polityki (Demokracja wymaga...). Prawdziwa i efektywna partycypacja obywateli w polityce uznawana jest za zjawisko kluczowe dla 
rozwoju silnej i stabilnej demokracji oraz najważniejszy postulat dla nowych państw demokratycznych. Żaden ustrój demokratyczny, żadne społeczeństwo obywatelskie nie może efektywnie funkcjonować bez zaangażowania wyborców, gdyż to właśnie udział uprawnionych w polityce jest warunkiem sine qua non istnienia demokratycznej formy rządów. Najważniejszymi z procedur umożliwiających obywatelom wpływ na życie polityczne są we współczesnych demokracjach głosowania powszechne - wybory i referenda, w których to najpełniej wyraża się zasada zwierzchnictwa narodu.

Niezaprzeczalnym jest fakt, iż idea udziału obywateli w procesie podejmowania decyzji państwowych stanowi istotną część historii europejskiej, szczególnie zaś nabrała znaczenia w kontekście przemian zachodzących na przełomie lat 80-tych i 90-tych w Europie Środkowej i Wschodniej. Tematyka partycypacji obywatelskiej od wielu lat absorbuje uwagę badaczy na całym świecie, a ostatnie lata są niewątpliwie dowodem wzmożonego zainteresowania szczególnie bezpośrednią formą demokracji na kontynencie europejskim. Jest to zapewne konsekwencją tego, iż zarówno w państwach Europy Zachodniej, w których istnieje solidnie ugruntowana demokracja, jak i w państwach byłego bloku wschodniego, demokracja bezpośrednia uzupełnia formę rządów przedstawicielskich (Linder, 1996, s. 226; Barber, 1984, s. 179-180), czego dowodem są zapewne liczne referenda organizowane przy wielorakich okazjach zarówno w państwach zachodnio- jak i środkowo- oraz wschodnioeuropejskich. Obserwatorzy reprezentujący np. m.in. Initiative and Referendum Institute - Europe, Democracy International, IDEA - International Institute for Democracy and Electoral Assistance czy inne organizacje pozarządowe, czy think thanki - są zgodni, że spośród wielu instytucji demokracji bezpośredniej szczególnie referendum przybiera obecnie coraz bardziej na znaczeniu, o czym świadczy duża liczba głosowań referendalnych, które miały miejsce w ciagu ostatnich 20-25 lat. Wynika to z faktu, iż wykorzystanie demokracji bezpośredniej najpierw „,sprowokowane” było przemianami ustrojowymi w państwach byłego bloku wschodniego, następnie zaś proces integracji europejskiej przyczynił się do bardziej wzmożonego niż wcześniej odwoływania się do opinii społeczeństwa właśnie za pośrednictwem instytucji referendum ogólnonarodowego.

Przedmiotem niniejszego tekstu są wybrane zagadnienia związane z partycypacją obywateli państw Gupy Wyszehradzkiej (Polska, Czechy, Słowacja, Węgry) w procesie „bezpośredniego” (tj. za pośrednictwem na- 
rzędzi demokracji bezpośredniej - głównie referendum) podejmowania najważniejszych decyzji politycznych, poczynając od tych, które wiązały się z procesem transformacji ustrojowej, a kończąc na tych, które poświęcone były akcesji do Unii Europejskiej. Prowadzone rozważania osadzone zostały w kontekście doświadczeń państw Europy Środkowej i Wschodniej. Na szczególną uwagę w tym zakresie zasługują referenda przeprowadzane w państwach Europy Środkowej i Wschodniej, które niewątpliwie w wielu przypadkach miały symboliczne znaczenie (niepodległość, czy akcesja do Unii Europejskiej). Głównym zamierzeniem badawczym niniejszego tekstu jest odpowiedź na pytanie o zakres udziału obywateli w państwach Grupy Wyszehradzkiej w procesie podejmowania decyzji politycznych po 1989 r. za pośrednictwem instytucji demokracji bezpośredniej, co z kolei pozwoli odpowiedzieć na pytanie o perspektywy wykorzystania bezpośrednich form sprawowania władzy w przyszłości.

Prowadzone rozważania w warstwie teoretycznej wspierają się przede wszystkim na dorobku autorów zagranicznych, m.in. Iana Budge (Budge, 1996; Cronin, 1989; LeDuc, 2003, Suksi, 1996).

W warstwie empirycznej posłużono się przede wszystkim danymi statystycznymi (dot. liczby, czasu, przedmiotu i wyników referendów). Dodatkowo - co jest niezwykle istotne w świetle członkostwa Polski, Czech, Słowacji i Węgier w Unii Europejskiej - rozważanie osadzono w kontekście wyników badań Eurobarometru. W tekście odniesiono się do badań opinii publicznej na temat: postaw obywateli względem Unii Europejskiej, demokracji jako takiej, a także demokracji w UE. Takie ujęcie problemu pozwoliło spojrzeć na wykorzystanie instytucji referendum w poszczególnych państwach, wskazać państwa z największą praktyką referendalną, a także określić lata największego wykorzystania referendum w procesach decyzyjnych w poszczególnych państwach. Analiza przedmiotów poszczególnych głosowań pozwoliła wskazać obszary tematyczne, które przedkładane są zwykle pod głosowanie. Niniejszy tekst nie stanowi wyczerpującej analizy tematu, może jednak stanowić przyczynek do dalszej dyskusji na temat udziału uprawnionych w głosowaniach „,bezpośrednich", a także na temat perspektyw wykorzystania w analizowanych państwach „bezpośrednich” form partycypacji obywatelskiej na poziomie UE. 


\section{Demokracja bezpośrednia w Europie Środkowej i Wschodniej - przykład referendów}

Analiza udziału obywateli państw europejskich oraz praktyki stosowania demokracji bezpośredniej, ze szczególnym uwzględnieniem referendum, upoważnia do stwierdzenia, że ta forma sprawowania demokratycznej władzy cieszy się dużym zainteresowaniem ${ }^{1}$. O tej popularności - oprócz liczby przeprowadzonych głosowań - świadczyć może wysoki poziom średniej frekwencji w głosowaniach powszechnych. Zarówno w Europie Zachodniej, jak i Środkowo-Wschodniej we wszystkich referendach przeprowadzonych od początku 1900 r. średnia partycypacja wyniosła około 66\%. Warto jednak zaznaczyć, iż w przypadku środkowej i wschodniej części kontynentu poziom udziału obywateli w procesach wyborczych może budzić wiele obaw. Badania wyników referendów w tzw. „młodych demokracjach" dowodzą, że największa frekwencja towarzyszyła głosowaniom w sprawach odzyskania niepodległości oraz akcesji do UE.

Przełomowym momentem w wykorzystaniu „bezpośredniej” formy rządzenia w państwach środkowo- i wschodnioeuropejskich był rok 1989. Okres ten wiązał się z początkiem przemian systemowych, zmierzających do wprowadzenia porządku demokratycznego w państwach, które do tej pory oddzielone były od państw zachodnich (demokratycznych) tzw. żelazna kurtynq. Od stycznia 1979 r. do końca czerwca 2014 r. przeprowadzono w tej części Europy łącznie 81 referendów.

Pod względem przedmiotowym wyróżnić można trzy grupy głosowań: niepodległościowe, ,pogłębiające przemiany” oraz akcesyjne.

\section{Referenda w sprawie odzyskania niepodległości}

Referenda niepodległościowe stanowią bez wątpienia istotną formę demokratyczną w procesie zmian ustrojowych w państwach byłego bloku. $\mathrm{W}$ wielu $\mathrm{z}$ nich to właśnie referenda w sprawie odzyskania niepodległości były początkiem przemian politycznych i społecznych. Nadmienić w tym miejscu należy, iż istotą głosowania w sprawie niepodległości jest prawne potwierdzenie woli narodu dążącego do zmiany swego statusu politycznego. Wyniki takich głosowań na ogół nie są wiążące, jednak rządzący po

Szerzej na ten temat w pracach m.in. M. Musiał-Karg, E. Zielińskiego, M. Gallaghera, M. Marczewskiej-Rytko, E. Kużelewskiej, B. Kaufmanna i in. 
wyrażeniu woli przez naród podejmują decyzje zgodne z opiniami wyborców.

Wysoka frekwencja wyborcza, towarzysząca głosowaniom niepodległościowym, stanowiła dowód na dużą mobilizację społeczeństw w rozpatrywanych państwach. We wszystkich referendach partycypacja wyniosła od około $62 \%$ do ponad $90 \%$. Oprócz wysokiej partycypacji wszystkim głosowaniom towarzyszyło jednoznaczne stanowisko wyborców. W dziesięciu na jedenaście referendów odpowiedzi twierdzące (na „Tak”) stanowiły ponad 70\%, z czego aż w siedmiu państwach - ponad 90\%. Wyniki ostatniego głosowania stanowią swojego rodzaju wyjątek w wachlarzu głosowań niepodległościowych - w tym przypadku 55\% uczestniczących opowiedziało się za niepodległością.

Tabela 1

Referenda niepodległościowe w Europie Środkowej i Wschodniej

\begin{tabular}{||l|r|l|c|c||}
\hline \multicolumn{1}{|c|}{ Państwo } & \multicolumn{1}{|c|}{ Data } & \multicolumn{1}{c|}{ Przedmiot } & $\begin{array}{c}\text { Frekwencja } \\
\mathbf{( \% )}\end{array}$ & Tak (\%) \\
\hline Słowenia & 23.12 .1990 & - niepodległość & 93,31 & 95,71 \\
\hline Litwa & 9.02 .1991 & - niepodległość & 84,74 & 93,24 \\
\hline Estonia & 3.03 .1991 & - niepodległość & 82,96 & 78,41 \\
\hline Łotwa & 3.03 .1991 & - niepodległość & 87,56 & 74,90 \\
\hline Ukraina & 17.03 .1991 & - suwerenność Ukrainy & 83,50 & 83,50 \\
\hline Chorwacja & 19.05 .1991 & - niepodległość & 84,94 & 93,24 \\
& & - pozostanie przy Jugosławii & 84,94 & 5,50 \\
\hline Macedonia & 8.09 .1991 & - niepodległość & 71,85 & 95,09 \\
\hline Ukraina & 1.12 .1991 & - niepodległość & 84,18 & 92,26 \\
\hline Bośnia i Hercegowina & 1.03 .1992 & - niepodległość & 62,45 & 99,69 \\
\hline Mołdawia & 6.03 .1994 & - niepodległość & 75,10 & 95,40 \\
\hline Czarnogóra & 21.05 .2006 & - niepodległość & 86,49 & 55,49 \\
\hline
\end{tabular}

Źródło: Research Centre on Direct Democracy, http://c2d.unige.ch/, 30.06.2014.

Dodatkowym elementem charakteryzującym referenda niepodległościowe był tzw. efekt domino. Referenda były przeprowadzane w bardzo niewielkim odstępie czasowym (jedno po drugim), co powodowało, iż wynik referendum w jednym państwie, wpływał na wynik kolejnych głosowań w państwach głosujących później.

Doświadczenia związane $\mathrm{z}$ przeprowadzaniem referendów niepodległościowych stanowią istotny wkład w dyskusję o znaczeniu demokracji 
bezpośredniej w środkowej i wschodniej części kontynentu, a także o roli obywateli w procesie decydowania politycznego. Wszystkie referenda zakończone zostały jednoznaczną odpowiedzią elektoratu, a w ich wyniku diametralnie zmieniła się mapa polityczna Europy. Odnotować jednak w tym miejscu należy, iż żadnego referendum niepodległościowego nie przeprowadzono w państwach wyszehradzkich.

\section{Referenda pogtębiajace przemiany (reformujace)}

Drugą kategorię referendów przeprowadzanych po roku 1990 w państwach środkowo- i wschodnioeuropejskich można określić jako referenda pogłębiajace, które to określenie miało zaakcentować fakt, iż kolejne (po niepodległościowych) głosowania referendalne w Europie Środkowej i Wschodniej miały na celu utrwalenie i pogłębienie zmian rozpoczętych na przełomie lat 80 -tych i 90 -tych. Należy tu wymienić przede wszystkim referenda w sprawie uchwalenia nowych konstytucji państwowych, referenda ustrojowe - np. w sprawie systemu wyborczego do parlamentu czy elekcji na prezydenta, czy głosowania w kwestii reform - np. prywatyzacji lub systemów ubezpieczeniowych.

Większość głosowań pogłębiajacych miała miejsce w latach 90-tych, jednak do tej kategorii można jeszcze dodać referendum konstytucyjne w Serbii - przeprowadzone w październiku roku 2006, które odbyło się pięć miesięcy po niepodległościowym głosowaniu w Czarnogórze.

Tabela 2

Wybrane referenda „pogłębieniowe” w państwach Europy Środkowej i Wschodniej

\begin{tabular}{|c|c|c|c|c|c|}
\hline Państwo & Data & Przedmiot & $\begin{array}{l}\text { Frekwen- } \\
\text { cja }(\%)\end{array}$ & $\begin{array}{l}\text { Tak } \\
(\%)\end{array}$ & Rezultat \\
\hline 1 & 2 & 3 & 4 & 5 & 6 \\
\hline Węgry & 26.10 .1989 & $\begin{array}{l}\text { - wybór prezydenta, } \\
\text { - rozwiązanie milicji zakładowych, } \\
\text { - rozliczenie majątku partii socjalis- } \\
\text { tycznej, } \\
\text { - usunięcie partii socjalistycznej z za- } \\
\text { kładów pracy }\end{array}$ & 58,04 & $\begin{array}{l}50,07 \\
94,93 \\
95,37 \\
95,14\end{array}$ & $\begin{array}{l}\text { przyjęte } \\
\text { przyjęte } \\
\text { przyjęte } \\
\text { przyjęte }\end{array}$ \\
\hline Rumunia & 8.12 .1991 & - konstytucja & 67,25 & 79,11 & przyjęte \\
\hline Litwa & 14.06 .1992 & $\begin{array}{l}\text { - bezwarunkowe wycofanie wojsk ra- } \\
\text { dzieckich }\end{array}$ & 76,05 & 92,27 & przyjęte \\
\hline Estonia & 28.06 .1992 & - konstytucja & 66,76 & 92,00 & przyjęte \\
\hline
\end{tabular}




\begin{tabular}{|c|c|c|c|c|c|}
\hline 1 & 2 & 3 & 4 & 5 & 6 \\
\hline Litwa & 25.10 .1992 & - konstytucja & 75,26 & 78,23 & przyjęte \\
\hline Litwa & 27.08 .1994 & - prywatyzacja (8 pytań) & 36,89 & ok. 89 & nieważne \\
\hline Słowacja & 22.10 .1994 & $\begin{array}{l}\text { - ujawnienie transakcji prywatyza- } \\
\text { cyjnych }\end{array}$ & 19,98 & 93,64 & nieważne \\
\hline Słowenia & 8.12 .1996 & $\begin{array}{l}\text { - system wyborczy do parlamentu } \\
\text { (3 propozycje) } \\
\text { A. wybory proporcjonalne; } \\
\text { B. model niemiecki; } \\
\text { C. model francuski }\end{array}$ & 37,94 & $\begin{array}{l}14,38 \\
44,52 \\
26,19\end{array}$ & $\begin{array}{c}\text { wszystkie } \\
\text { propozycje } \\
\text { odrzucone }\end{array}$ \\
\hline Polska & 18.02 .1996 & $\begin{array}{l}\text { - powszechne uwłaszczenie obywateli, } \\
\text { - zobowiązanie wobec emerytów, re- } \\
\text { ncistów oraz pracowników sfery } \\
\text { budżetowej - zaspokajane z prywa- } \\
\text { tyzowanego majątku państwowego } \\
\text { - zasilenie części powszechnych fun- } \\
\text { duszy emerytalnych częścią prywa- } \\
\text { tyzowanego majątku } \\
\text { - zwiększenie świadectw udziałowych } \\
\text { NFI } \\
\text { - bony prywatyzacyjne w programie } \\
\text { uwłaszczeniowym }\end{array}$ & $\begin{array}{l}32,44 \\
32,44 \\
32,44 \\
32,44\end{array}$ & $\begin{array}{l}92,89 \\
93,70 \\
21,86 \\
88,30\end{array}$ & nieważne \\
\hline Polska & 27.04 .1997 & - konstytucja & 42,86 & 52,70 & przyjęte \\
\hline Słowacja & 26.09 .1998 & $\begin{array}{l}\text { - nieprywatyzowanie strategicznie } \\
\text { ważnych przedsiębiorstw }\end{array}$ & 44,06 & 84,30 & nieważne \\
\hline Serbia & 29.10 .2006 & - konstytucja & 55,00 & 53,00 & przyjęte \\
\hline
\end{tabular}

Źródlo: Research Centre on Direct Democracy, http://c2d.unige.ch/, odczyt z 30.06.2014 r.

Referenda pogtębiajace dotyczyły relatywnie dużego spektrum spraw - od kwestii konstytucyjnych poprzez ustrojowe, związane z wycofaniem wojsk radzieckich aż do problemów prywatyzacyjnych. Referendom przeprowadzanym w tym czasie nie towarzyszył efekt domino, który dostrzec można było w przypadku głosowań niepodległościowych.

Najbardziej widoczną cechą referendów pogłębiajacych była dużo niższa - niż w przypadku głosowań niepodległościowych - frekwencja wyborcza. Podczas gdy w referendach w sprawie niepodległości partycypacja osiagała poziom przekraczający nawet $90 \%$, to późniejsze głosowania charakteryzowały się frekwencją niższą - nawet na poziomie $30-40 \%$, co też stało się powodem niespełnienia przez niektóre referenda warunków ważności (np. Słowacja). Kolejną istotną właściwością referendów pogłębiających było dużo mniejsze poparcie społeczeństwa dla proponowanych w głosowaniach zmian. Głosowania pogtębiajace mogą być traktowane jako dowód na to, że w po entuzjazmie związanym z początkiem zmian ustrojowych - pozy- 
tywne emocje opadają a zaangażowanie społeczne w sprawy - jak się wydaje - o mniej symbolicznym znaczeniu - słabnie.

\section{Referenda w sprawie akcesji do Unii Europejskiej}

W procesie przemian demokratycznych w Europie Środkowej i Wschodniej bardzo ważną rolę odegrały referenda akcesyjne, które przeprowadzono w roku 2003 - przy okazji największego rozszerzenia Unii Europejskiej oraz - jak w przypadku Chorwacji w roku 2012.

Akcesja do Unii Europejskiej postrzegana była jako symboliczne dołączenie do zachodnich demokracji i od czasów transformacji była jednym z priorytetowych celów polityki zagranicznej państw byłego bloku. Wstąpienie do Unii było więc sprawą uznaną za powszechnie ważną, nie identyfikowaną z interesem jednostek, ale związaną zarówno z przyszłością wszystkich obywateli, jak i następnych pokoleń. Wypada zwrócić uwagę, że referendom akcesyjnym w każdym z państw towarzyszył walor niepowtarzalności, a ich rezultatom - walor historycznej nieodwracalności. Przewidywano więc, iż frekwencja w głosowaniach będzie wysoka, a społeczne poparcie dla przyłączenia się poszczególnych państw do Wspólnoty będzie także na wysokim poziomie (Musiał-Karg, 2008, s. 287).

Tabela 3

Referenda akcesyjne w Europie Środkowo-Wschodniej

\begin{tabular}{|l|r|r|c|c||}
\hline \multicolumn{1}{|c|}{ Państwo } & \multicolumn{1}{c|}{ Data } & Przedmiot & Frekwencja (\%) & Tak (\%) \\
\hline Malta & 8.03 .2003 & - akcesja do UE & 90,85 & 53,65 \\
\hline Słowenia & 23.03 .2003 & - akcesja do UE & 60,43 & 89,64 \\
\hline Węgry & 12.04 .2003 & - akcesja do UE & 45,63 & 83,76 \\
\hline Litwa & $10-11.05 .2003$ & - akcesja do UE & 63,30 & 89,93 \\
\hline Słowacja & $16-17.05 .2003$ & - akcesja do UE & 52,15 & 92,46 \\
\hline Polska & $7-8.06 .2003$ & - akcesja do UE & 58,85 & 77,45 \\
\hline Czechy & $13-14.06 .2003$ & - akcesja do UE & 55,21 & 72,33 \\
\hline Estonia & 14.09 .2003 & - akcesja do UE & 64,06 & 66,83 \\
\hline Lotwa & 20.09 .2003 & - akcesja do UE & 73,12 & 67,48 \\
\hline Chorwacja & 22.01 .2012 & - akcesja do UE & 43,51 & 66,27 \\
\hline
\end{tabular}

Źródło: Initiative \& Referendum Monitor 2004/2005. The IRI Europe Toolkit for Free and Fair Referendums and Citizens' Initiatives, red., B. Kaufmann, Amsterdam 2004, s. 9; Research Centre on Direct Democracy, http://c2d.unige.ch/, odczyt z 30.06.2014 r.; M. Musiał-Karg, Referenda w państwach europejskich. Teoria, praktyka, perspektywy, Toruń 2008, s. 284-294. 
We wszystkich referendach uczestniczący jednoznacznie poparli członkostwo w Unii, a w każdym z państw więcej niż 50\% uczestniczących poparła akcesję. W krajach, w których wymagano osiagnięcia jakiejś minimalnej frekwencji dla uznania wyniku referendum za wiążący (Litwa, Słowacja, Polska, a także Łotwa i Węgry) ${ }^{2}$ (Dziewulski, Otechel, 2003, s. 59, Musiał-Karg, 2008, s. 257) warunek ten został spełniony. Aby nieco zniwelować zagrożenie zbyt niskiej frekwencji na Litwie, w Polsce, Słowacji czy Czechach postanowiono wydłużyć czas oddawania głosów i zorganizowano tam dwudniowe referenda, zakładając, że dodatkowy dzień wyborczy wpłynie na zwiększenie partycypacji.

Zauważyć należy, iż w przypadku referendów z 2003 r. niezwykle istotna okazała się kolejność przeprowadzania głosowań w poszczególnych krajach kandydujących. Różny stopień poparcia umożliwiał wpływanie na preferencje wyborców poprzez funkcjonowanie wspomnianego już wcześniej efektu domino.

Reasumując, należy podkreślić, iż głosowania akcesyjne z 2003 r. i 2012 r. miały szczególne znaczenie dla przyszłych państw członkowskich z Europy Środkowej i Wschodniej, ponieważ stanowiły symboliczne „zamknięcie rozdziału łączącego te państwa z byłym blokiem wschodnim" - stanowiły niejako finalny krok na tej drodze. Ponadto referenda akcesyjne w większości państw były pierwszymi głosowaniami powszechnymi o tematyce stricte ,europejskiej”.

\section{Demokracja bezpośrednia w państwach Grupy Wyszehradzkiej}

W świetle doświadczeń Europy Środkowej i Wschodniej stwierdzić można, iż wszystkie państwa wyszehradzkie mają doświadczenia referendalne, co z jednej strony stanowi zapewne niezwykle istotny fakt z punktu widzenia rozwoju tamże demokracji bezpośredniej. $Z$ drugiej jednak strony zauważyć należy, iż doświadczenia dwu z rozpatrywanych państw

2 Na Litwie, w Słowacji i w Polsce, aby głosowanie było wiążące, musiała w nim uczestniczyć przynajmniej połowa obywateli uprawnionych do głosowania. Na Łotwie głos musiało oddać co najmniej ok. 497 tysięcy wyborców (35,14\% osób uprawnionych do głosowania), tj. co najmniej połowa głosujących w ostatnich wyborach parlamentarnych. Na Węgrzech wynik referendum uważa się za wiążący, jeżeli któraś z odpowiedzi na pytanie referendalne („Tak” lub „Nie”) uzyska taką liczbę głosów, która stanowić będzie ponad 25\% głosów wszystkich uprawnionych do głosowania. 
- Czech i Słowacji - określone moga być jako dość ograniczone (jak w przypadku Czech - jedno referendum) lub trudne (jak w Słowacji, gdzie w większości głosowań nie osiągnięto wymaganej frekwencji).

Tabela 4

Referenda w państwach Grupy Wyszehradzkiej

\begin{tabular}{||l|c|c|c|}
\hline \multicolumn{1}{|c|}{ Państwo } & $\begin{array}{c}\text { Liczba referendów } \\
\text { po 1989 r. }\end{array}$ & Liczba pytań & Ostatnie referendum \\
\hline Czechy & 1 & 1 & 2003 \\
\hline Polska & 3 & 7 & 2003 \\
\hline Węgry & 6 & 12 & 2008 \\
\hline Słowacja & 7 & 15 & 2010 \\
\hline Razem & 17 & 35 & \\
\hline
\end{tabular}

Źródło: Opracowanie własne.

Jak widać w powyższej tabeli, łączna liczba referendów w rozpatrywanych państwach w okresie od stycznia 1989 do czerwca 2014 r. wyniosła 17, a wyborcy udzielali odpowiedzi na łącznie 35 pytań.

\section{Postawy obywateli państw Grupy Wyszehradzkiej w kontekście czlonkostwa w UE}

Jednym z ważnych wymiarów funkcjonowania państw Grupy Wyszehradzkiej jest Unia Europejska, której członkami Czechy, Polska, Słowacja i Węgry są od 1 maja 2004 r.

Bez żadnych wątpliwości stwierdzić należy, iż w wyniku nowego miejsca państw V4 w Europie - przez ostatnią dekadę Polska, Czechy, Węgry i Słowacja znacząco zyskały gospodarczo i stały się silniejszymi aktorami na arenie międzynarodowej. Potwierdzają to badania analityków z Erste Group Polska, którzy przygotowali raport podsumowujący 10 lat członkostwa państw Grupy Wyszehradzkiej w UE.

We wspomnianym raporcie wskazano korzyści, jakie kraje te odniosły wskutek obecności we Wspólnocie, ale i wyzwania stojące przed nimi. I tak, dzięki członkostwu w UE produkt krajowy brutto (PKB) państw Grupy Wyszehradzkiej rósł dodatkowo o ok. 1\% rocznie. Każde z czterech państw odnotowało też wzrost PKB w przeliczeniu na mieszkańca - Słowacja i Polska ponad dwukrotny. 
Wykres 1. Wzrost dochodu narodowego w państwach Grupy Wyszehradzkiej

PKB na osobę w państwach Grupy Wyszehradzkiej w 2003 i 2013 r., w tys. euro

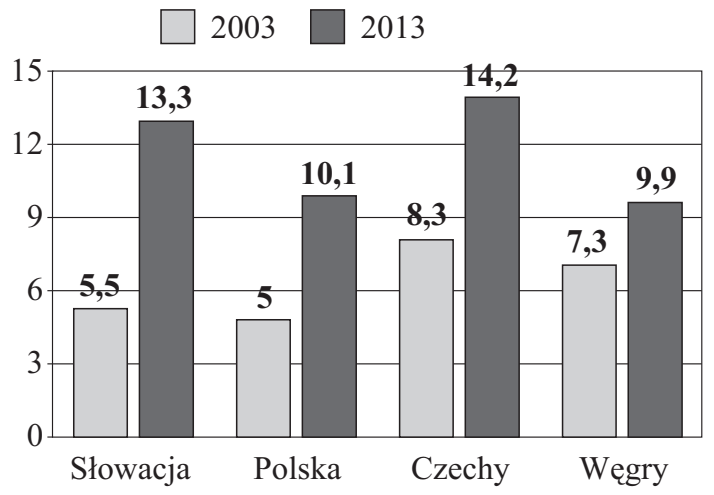

Wzrost PKB na osobę w państwach Grupy Wyszehradzkiej od ich wejścia do UE, w proc.

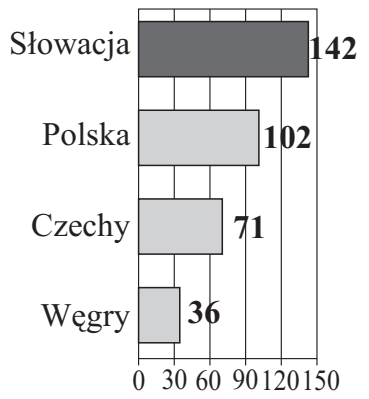

Źródło: Grupa Wyszehradzka silniejsza dzięki Unii, http://archiwum.rp.pl/artykul/1241210-Grupa-Wyszehradzka-silniejsza-dzieki-UE.html, 26.11.2014.

Jak pokazuje wskaźnik jakości życia (współczynnik mierzący nie tylko dobrobyt materialny, ale również inne zmienne, takie jak średnia długość życia, wczesne kończenie nauki, dobrostan materialny, nierówności dochodowe, zróżnicowanie wynagrodzenia ze względu na płeć, liczba zabójstw itp.), trzy spośród czterech państw V4 awansowały w rankingu jakości życia, natomiast Czechy wyprzedziły w tym obszarze Włochy i Wielką Brytanię. Słowacja, Czechy i Polska znalazły się w gronie pięciu państw o najwyższej zwyżce notowań w ciągu ubiegłej dekady. Węgry uplasowały się zaś tuż za Grecją z drugim największym spadkiem w rankingu (Grupa Wyszehradzka silniejsza...).

Analizując powyższy wykres, sformułować można wniosek, że 10 lat po przystąpieniu do UE postęp społeczno-ekonomiczny państw grupy V4 jest znaczący. Dzięki członkostwu w UE nastąpił wzrost zarówno siły gospodarczej, jak i znaczenia tych państw. Biorąc zatem pod uwagę korzystny gospodarczy bilans członkostwa państw Grupy Wyszehradzkiej w Unii Europejskiej, należałoby zastanowić się czy przełożyło się to na nastroje społeczne względem UE, na zainteresowanie obywateli analizowanych państw sprawami Unii, a także na zaangażowanie obywateli np. w wyborach do PE czy w inne instytucje demokratyczne na poziomie Wspólnoty. Dane te mogą bowiem odpowiedzieć na pytanie, czy obywatele są zainte- 
resowani angażowaniem się na płaszczyźnie UE i czy będą korzystali z instrumentów demokratycznych oferowanych im przez Unię.

Otóż z badań Eurobarometru wynika, że najbardziej entuzjastycznie do UE nastawieni są Polacy, następnie Słowacy i porównywalnie Węgrzy i Czesi. Na tle mieszkańców innych państw Grupy Wyszehradzkiej, Polacy najlepiej oceniają członkostwo swojego kraju w Unii Europejskiej. Prawie cztery piąte respondentów Eurobarometru (78\%) uważa, że Polska skorzystała na przystapieniu do wspólnoty, a niemal (53\%) sądzi, że obecność w UE jest czymś dobrym dla kraju. O korzystnym bilansie integracji przekonana jest też dominująca część Słowaków - 72\% dostrzega korzyści dla Słowacji i 50\% twierdzi, że integracja jest czymś dobrym dla kraju. Stosunkowo najmniejszy euroentuzjazm przejawiają Czesi i Węgrzy. Odpowiednio 57 i 47\% uważa, że integracja jest korzystna dla nich, a tylko $31 \%$ Czechów i 29\% Węgrów ocenia przynależność do struktur unijnych jako coś dobrego.

Tabela 5

Przywiązanie i przynależność do Unii Europejskiej - opinie respondentów z państw Grupy Wyszehradzkiej

\begin{tabular}{||l|c|c|c|c||}
\hline \multirow{2}{*}{\multicolumn{1}{|c|}{ Pytanie }} & \multicolumn{4}{c||}{ Państwo } \\
\cline { 2 - 5 } & Polska & Slowacja & Czechy & Węgry \\
\hline $\begin{array}{l}\text { Czy członkostwo naszego kraju w UE jest } \\
\text { czymś dobrym? Odp.: Tak }\end{array}$ & $53 \%$ & $50 \%$ & $31 \%$ & $39 \%$ \\
\hline $\begin{array}{l}\text { Czy nasz kraj skorzystał z członkostwa } \\
\text { z UE? Odp.: Tak }\end{array}$ & $78 \%$ & $72 \%$ & $57 \%$ & $47 \%$ \\
\hline Czy mój głos liczy się w UE? Odp.: Tak & $65 \%$ & $56 \%$ & $42 \%$ & $54 \%$ \\
\hline $\begin{array}{l}\text { Czy jest Pan(i) zadowolony(a) z funkcjo- } \\
\text { nowania demokracji w UE? Odp.: Tak }\end{array}$ & $65 \%$ & $46 \%$ & $51 \%$ & $52 \%$ \\
\hline $\begin{array}{l}\text { Czy jest Pan(i) zainteresowana sprawami } \\
\text { europejskimi? Odp.: Tak }\end{array}$ & $53 \%$ & $36 \%$ & $25 \%$ & $43 \%$ \\
\hline
\end{tabular}

Źródło: Opracowanie własne na podstawie Eurobarometru „Na rok przed wyborami europejskimi 2014". Zasięg badania UE 28(27.624), metoda - wywiad bezpośredni, termin badania 7-23 V 2013. http://www.europarl.europa.eu/pdf/eurobarometre/2013/election/eb79_5_synthese_institutionnelle_pl.pdf.

Poniższa tabela przedstawia wybrane dane z badania Eurobarometru, które postanowiono powiązać z postawami obywateli V4 wobec: po pierwsze - UE, po drugie - demokracji w UE. Przyjęto bowiem założenie, że korzyści płynące z członkowstwa ww. państw w UE generowały będą 
pozytywne postawy - po pierwsze względem UE, a po drugie - wglądem unijnej demokracji.

Odpowiedzi na uwzględnione pytania wskazują, że po pierwsze - mimo zróżnicowanych opinii na temat pozytywnej oceny faktu członkostwa danego państwa w UE, większość obywateli widzi korzyści płynące z przyłączenia się ich państwa do Unii (od 47\% odpowiedzi „Tak” na Węgrzech do $78 \%$ pozytywnych odpowiedzi w Polsce). Odnotować należy, że większość respondentów uważa, że ich głos ma znaczenie w UE, co jest istotne bowiem - jak wskazują badania - największym problemem w kontekście upodmiotowienia obywali - jest ich brak poczucia wpływu na ważne dla nich kwestie. W tym przypadku - widać, że średnio około 54\% obywateli V4 ma przekonanie o ważności swojego głosu. Pozytywne opinie obserwowalne są także w kontekście odpowiedzi na pytanie o zadowolenie obywateli $\mathrm{z}$ funkcjonowania demokracji w UE. W trzech z czterech rozpatrywanych państw ponad połowa respondentów odpowiedziała pozytywnie. W tym przypadku (zresztą podobnie jak w przypadku poprzedniego pytania) można mieć jednak pewne wątpliwości, co spowodowane jest analizą frekwencji wyborczej w Polsce, Słowacji, Czechach i na Węgrzech w wyborach do Parlamentu Europejskiego.

Tabela 6

Frekwencja wyborcza w wyborach do PE w 2014 r.

w państwach Grupy Wyszehradzkiej

\begin{tabular}{|r|c|c|c|}
\hline \multicolumn{4}{|c|}{ UE - 42,54\% } \\
\hline Polska & Slowacja & Czechy & Węgry \\
\hline $23,83 \%$, & $13,05 \%$, & $18,20 \%$ & $28,97 \%$, \\
\hline
\end{tabular}

Źródło: Parlament Europejski, http://www.europarl.europa.eu/elections2014-results/pl/turnout.html, 26.11.2014.

Jak widać w powyższej tabeli, frekwencja w wyborach do Parlamentu Europejskiego w analizowanych państwach należy do najniższych w Europie, co z kolei może sugerować, iż obywatele wspomnianych państw są po pierwsze, mało zainteresowani sprawami europejskimi lub też - nie mają wiedzy na temat funkcjonowania PE oraz jego wpływu na polityczną rzeczywistość w każdym państwie członkowskim. Nie zmienia to również faktu, iż małe zaangażowanie w wyborach do PE może przekładać się również na niewielkie zaangażowanie obywatelskie w inne przedsięwzięcia na poziomie unijnym. 
Wydaje się, że niska partycypacja obywatelska w wyborach do PE (mimo dużej partycypacji $\mathrm{w}$ referendum akcesyjnym, generalnie pozytywnych ocen członkostwa w UE oraz dostrzegania korzyści płynących z członkostwa w UE) przekładać się może także na niewielką aktywność na płaszczyźnie związanej z unijną demokracją. Przykładem tego może być zapewne Europejska Inicjatywa Obywatelska.

W dyskusji nad demokracją bezpośrednią w Unii Europejskiej pojawiało się wiele wątków związanych z ustanowieniem - wspólnych ,unijnych" instrumentów podejmowania decyzji przez obywateli UE.

Mimo iż pomysły ustanowienia instytucji europejskiej inicjatywy powszechnej pojawiły się już w latach 80-tych i 90-tych, to przepisy ustanawiające europejską inicjatywę obywatelską uchwalono dopiero Traktatem z Lizbony.

Przepisy dotyczące europejskiej inicjatywy obywatelskiej zostały zdefiniowane w art. 11 ust. 4 Traktatu, który brzmi: „Obywatele Unii w liczbie niemniejszej niż milion, mający obywatelstwo znacznej liczby Państw Członkowskich, mogą podjąć inicjatywę zwrócenia się do Komisji Europejskiej o przedłożenie, w ramach jej uprawnień, odpowiedniego wniosku w sprawach, w odniesieniu do których, zdaniem obywateli, stosowanie Traktatów wymaga aktu prawnego Unii". Inicjatywa obywatelska może dotyczyć każdej z dziedzin, w których Komisja Europejska ma uprawnienia do przedkładania wniosków legislacyjnych. Aby nadać bieg inicjatywie obywatelskiej, musi ona zostać poparta przez co najmniej milion obywateli UE pochodzących z przynajmniej 7 spośród państw członkowskich UE.

Europejskie Inicjatywy obywatelskie, w które zaangażowane są państwa Grupy Wyszehradzkiej

\begin{tabular}{||l|l||}
\hline \multicolumn{1}{|c|}{ Tytul inicjatywy } & $\begin{array}{c}\text { Uczestnicy } \\
\text { z V4 }\end{array}$ \\
\hline $\begin{array}{l}\text { 1. New deal 4 Europe - for European special plan for sustainable development } \\
\text { and employment (otwarta) }\end{array}$ & Cz., H \\
\hline \begin{tabular}{l} 
2. European Free Vaping Initiative (zbieranie podpisów zakończone) \\
\hline 3. European Initiative for Media Pluralism (zbieranie podpisów zakończone)
\end{tabular} & Pl, H \\
\hline 4. Stop vivisection (zbieranie podpisów zakończone) & PL, Cz., SK, H \\
\hline 5, One of us (Answered by the Commission) (zbieranie podpisów zakończone) & H, PL, SK \\
\hline $\begin{array}{l}\text { 6. Water and sanitation are a human right! Water is a public good, not a commo- } \\
\text { dity! (Answered by the Commission) (zbieranie podpisów zakończone) }\end{array}$ & H, PL, SK \\
\hline
\end{tabular}

Source: European Citizens' Initiative, http://ec.europa.eu/citizens-initiative/public/initiatives/ ongoing, 26.11.2014. 
W tabeli przedstawiono europejskie inicjatywy obywatelskie, w które zaangażowane są państwa Grupy Wyszehradzkiej. Zestawienie to jest o tyle istotne, iż pozwala zwrócić uwagę na dwie istotne sprawy. Po pierwsze, relatywnie mały udział państw V4 w realizowaniu europejskiej inicjatywy ludowej (znacznie większy jest udział państwa pozostałych - szczególnie z Europy Zachodniej); po drugie, kwestie poddawane pod inicjatywę obywatelską stanowią raczej zagadnienie drugorzędne dla polityk UE, a także dla interesów państw Grupy Wyszehradzkiej.

Analiza dostępnych głównie na stronach internetowych Komisji Europejskiej danych na temat składanych inicjatyw europejskich pozwala przypuszczać, iż nie będzie to efektywne narzędzie decydowania politycznego wykorzystywane przez obywateli UE, a na pewno przez obywateli państw Europy Środkowej i Wschodniej (w tym z państw V4). Supozycje te wynikają przede wszystkich z analizy przedmiotów złożonych inicjatyw, które nie należą raczej do kwestii o priorytetowej roli. Wydaje się, że traktaty unijne o kluczowym dla UE znaczeniu czy reformy w ramach Unii nie będą przedmiotem europejskich inicjatyw obywatelskich, co bez wątpienia „obniża” niejako rangę tego instrumentu. Głosowania nad tymi kwestiami będą odbywały się zapewne na forach narodowych parlamentów, a w niektórych przypadkach z udziałem obywateli w głosowaniach referendalnych.

\section{Podsumowanie}

Praktycznie we wszystkich państwach Europy Środkowej i Wschodniej (ze szczególnym uwzględnieniem państw Grupy Wyszehradzkiej) debata na temat zaangażowania obywateli w proces podejmowania decyzji państwowych (zarówno za pośrednictwem narzędzi demokracji przedstawicielskiej, jak i bezpośredniej) ze względów historycznych i politycznych miała miejsce znacznie później niż w państwach zachodnioeuropejskich.

Podstawę do włączenia obywateli w życie publiczne stanowiły reformy przeprowadzane w pierwszej połowie lat 90 -tych. Istotne w tym czasie stały się zarówno kwestie prywatyzacyjne, jak i konstytucyjne, które usankcjonowały obywateli jako aktorów na rynku gospodarczym i społecznym, a także przewartościowały i upodmiotowiły ich w procesie podejmowania decyzji (Poczykowska, 2013, s. 49). Część z - jak można rzec - demokratyzacyjnych (pogłębiających pierwotne zmiany) decyzji podej- 
mowana była z udziałem obywateli, którzy mieli możliwość wypowiadania się za pośrednictwem referendum ogólnonarodowego.

Okres przemian polityczno-społecznych zakończony niejako został przystapieniem państw byłego bloku do Unii Europejskiej, co poprzedzone zostało symbolicznymi referendami w sprawie ratyfikacji traktatów akcesyjnych. Przypomnieć należy, iż w przepadku Czech - referendum akcesyjne było pierwszym głosowaniem „bezpośrednim” w tym państwie. Członkostwo w Unii Europejskiej, a następnie ratyfikacja Traktatu z Lizbony dały obywatelom UE (w tym obywatelom państw wyszehradzkich) dodatkowe możliwości bezpośredniego wpływania na sprawy europejskie - za pośrednictwem europejskiej inicjatywy obywatelskiej.

Biorąc pod uwagę udział obywateli w procesie podejmowania decyzji, zauważyć należy, iż w rozpatrywanych państwach formy demokracji bezpośredniej są wykorzystywane do rozstrzygania najważniejszych kwestii politycznych, spraw o walorze niepowtarzalności i historycznej nieodwracalności (kwestie niepodległościowe, reformy polityczne oraz akcesja do UE). Takim głosowaniom powszechnym towarzyszy zazwyczaj wysoka frekwencja wyborcza oraz niemalże jednoznaczne stanowisko wyborców.

Odnotować także należy, iż państwa wyszehradzkie, a także cała Europa Środkowa i Wschodnia to region, gdzie w ciagu ostatnich dwudziestu kilku lat demokracja bezpośrednia - a przede wszystkim referenda - organizowane były relatywnie często. Nadmienić warto, że wszystkie państwa $\mathrm{z}$ tej części kontynentu skorzystały przynajmniej jednokrotnie $\mathrm{z}$ tej instytucji.

W tzw. „młodych demokracjach” - a do takich zalicza się Polskę, Czechy, Słowację i Węgry - pomimo wykorzystywania form demokracji bezpośredniej w celu rozwiązywania kwestii o kluczowym znaczeniu, trudno mówić o sprawdzonej praktyce odwoływania się do tej formy - m.in. ze względu na negatywne doświadczenia sięgające okresu sprzed 1989 r., a także problemy z frekwencją w referendach (np. Słowacja).

Godnym uwagi jest również fakt, że w ostatnich latach oczywistym stało się, iż kwestie związane z Unią Europejską zdominowały zakres przedmiotowy referendów w wielu państwach - zarówno tych należący do UE, jak i tych niebędących jeszcze jej członkami. Pozwala to przypuszczać, iż kolejnym pretekstem do przeprowadzenia referendów ogólnokrajowych w państwach Grupy Wyszehradzkiej będzie kwestia wejścia w strefę euro i przyjęcie europejskiej waluty. Powszechne są propozycje wielu polityków, by poddać te kwestie decyzji obywateli (mimo iż decyzja o przyjęciu euro podjęta została już w referendum akcesyjnym). 
W kontekście członkostwa państw wyszehradzkich w UE, przypuszczać można, iż europejska inicjatywa obywatelska nie będzie zbyt popularnym przedmiotem zainteresowania w państwach wyszehradzkich, co może być wynikiem generalnie małego zaangażowania obywateli w życie polityczne na poziomie państwowym, a także małej świadomości dotyczącej funkcjonowania Unii Europejskiej.

\section{Bibliografia}

Barber B. (1984), Strong Democracy. Participatory Politics for a New Age, Berkley-London.

Budge I. (1996), The New Challenge of Direct Democracy, Cambridge.

Centre for Research on Direct Democracy, http://c2d.unige.ch/.

Cronin T. E. (1989), Direct Democracy. The Politics of Initiative, Referendum, and Recall, Cambridge, Massachusetts-London.

Demokracja wymaga partycypacji politycznej obywateli, Dom Wszystkich Polska, http://www.dwp.org.pl/aktualnosci/podlasie/articles/98-demokracja-wymaga-partycypacji-politycznej-obywateli, 13.12.2014.

Dziewulski R., Otachel B. (2003), Referenda akcesyjne na Litwie, Stowacji, Czechach, Estonii i Łotwie, „Biuletyn Analiz UKIE”, nr 13.

European Citizens' Initiative, http://ec.europa.eu/citizens-initiative/public/initiatives/ ongoing, 26.11.2014.

Grupa Wyszehradzka silniejsza dzięki Unii, http://archiwum.rp.pl/artykul/1241210-Grupa-Wyszehradzka-silniejsza-dzieki-UE.html, 26.11.2014.

LeDuc L. (2003), The Politics of Direct Democracy: Referendums in Global Perspective, Buffalo.

Linder W. (1996), Demokracja szwajcarska. Rozwiazywanie konfliktów w społeczeństwie wielokulturowym, Rzeszów.

Maszkowska A., Sztop-Rutkowska K. (2013), Partycypacja obywatelska - decyzje bliższe ludziom, Fundacja Laboratorium Badań i Działań Społecznych „SocLab”, Białystok.

Musiał-Karg M. (2008), Referendum w państwach europejskich. Teoria, praktyka, perspektywy, Torun.

Parlament Europejski, http://www.europarl.europa.eu/elections2014-results/p1/turnout.html, 26.11.2014.

Poczykowska K. (2013), Rola i znaczenie partycypacji publicznej, w: Partycypacja obywatelska - decyzje bliższe ludziom, red. A. Maszkowska, K. Sztop-Rutkowska, Fundacja Laboratorium Badań i Działań Społecznych „SocLab”, Białystok. 
Suksi M. (1993), Bringing in the People. A Comparison of Constitutional Forms and Practices of the Referendum, Dordrecht.

Szczegóła L. (2013), Bierność obywateli. Apatia polityczna w teorii demokratycznej partycypacji, Elipsa, Warszawa.

From transformation to integration: selected remarks concerning the direct' participation of citizens in the process of political decision-making after 1989 on the example of the Visegrad Group states

\section{Summary}

The subject of this paper concerns selected experiences of citizens from the Visegrad Group countries (Poland, the Czech Republic, Slovakia and Hungary) participating in the process of 'direct' (that is, exercised by means of the tools of direct democracy) decision making as regards the most important matters, ranging from those related to the process of political transformation to the decision on accession to the European Union. The present considerations dwell on the experiences of Central and East European countries. 